\title{
Polypyrrole micro actuators
}

Edwin Jager, Elisabeth Smela, Olle Inganäs and Ingemar Lundström

\section{Linköping University Post Print}

N.B.: When citing this work, cite the original article.

Original Publication:

Edwin Jager, Elisabeth Smela, Olle Inganäs and Ingemar Lundström, Polypyrrole micro actuators, 1999, Synthetic metals, (102), 1-3, 1309-1310.

http://dx.doi.org/10.1016/S0379-6779(98)01000-5

Copyright: Elsevier

http://www.elsevier.com/

Postprint available at: Linköping University Electronic Press

http://urn.kb.se/resolve?urn=urn:nbn:se:liu:diva-60383 


\title{
POLYPYRROLE MICROACTUATORS
}

\author{
Edwin W.H. Jager ${ }^{*}$; Elisabeth Smela ${ }^{2}$; Olle Inganäs ${ }^{1}$; Ingemar Lundström ${ }^{1}$ \\ ${ }^{1}$ Laboratory of Applied Physics, IFM, Linköpings universitet, S-581 83 Linköping, Sweden \\ ${ }^{2}$ Condensed Matter Department, Risø National Lab, FYS-124, P.O. Box 49, DK-4000 Roskilde, Denmark
}

\begin{abstract}
The doping and undoping of conjugated polymers is accompanied by a volume change. This volume change can be used to make micro-actuators. We have built polypyrrole (PPy) gold bilayer structures. The volume change of PPy induces a bending of the bilayer. We have made micro-actuators based on this principle, which have been examined with video-microscopy. Some applications for these micro-actuators are proposed, including opening and closing boxes for cell biology and nanoliter chemistry and micro-robotics.
\end{abstract}

Keywords: actuator, microfabrication, conjugated polymers, polypyrrole, electrochemistry

\section{Introduction}

By applying a voltage conjugated polymers can be doped and undoped. This doping and undoping can lead to a change in conductivity, colour, and volume. The volume change can be used to make actuators. Several actuators (also called bending beams) based on a bilayer principle, in which the volume of one layer is changed while the volume of the other layer is either held constant or changed in the opposite direction, have been presented. [1-4].

Using standard photolithographic techniques, $\mathrm{PPy} / \mathrm{Au}$ microactuators (or micromuscles) based on the bending beam principle have been developed in our laboratory [5].

\section{Fabrication}

We started with a silicon wafer on which thin $\mathrm{Cr}$ and $\mathrm{Au}$ layers were evaporated. The chromium layer is necessary as an adhesion layer because the gold it self adheres poorly to silicon. The gold layer was in turn used to prevent oxidation of the chromium and to adhere a second, structural gold layer later in the procedure. Next, windows were etched in the chromium and gold layers. These windows are necessary for the last release step. This method called differential adhesion is used rather than using a sacrificial layer. Following that, the $1000 \AA$ structural gold layer was deposited by evaporation.

For the active part in the hinges, polypyrrole was deposited. The polymer is electrochemically grown on the gold surface from a $0.1 \mathrm{M}$ pyrrole, $0.1 \mathrm{M}$ NaDBS (dodecyl benzene sulfonic acid, sodium salt) solution at a voltage of $0.5 \mathrm{~V}$ vs. $\mathrm{Ag} / \mathrm{AgCl}$ with a gold counter electrode. During the growth large immobile DBS anions were incorporated into the polymer film and the polypyrrole became doped. The polypyrrole was patterned by growing it in windows in a layer of photoresist.
The last step was to remove the excess gold to free the structures (hinges and lids). Although the structures were now free, they were still attached to the surface.

\section{Experimental}

Cyclovoltammetry was used to operate the microactuators using an Eco Chemie potentiostat. We used a voltage from 0 to -1 $\mathrm{V}$ versus an $\mathrm{Ag} / \mathrm{AgCl}$ reference, with a scan rate of $100 \mathrm{mV} / \mathrm{s}$. After a few initial cycles the microactuators released themselves from the substrate.

As mentioned in the first section, the bending is caused by a shrinking/swelling of the PPy layer due to a redox reaction. When grown, the PPy is in its oxidised state and large immobile DBSanions are incorporated in the film. During the first redox cycle an irreversible volume change occurs. The volume remains constant during the first reduction and a large cathodic current peak is observed. The volume of the PPy decreases during the following oxidation. In the following redox cycles the volume increases during reduction $\left(\mathrm{V}_{\mathrm{appl}}=-1 \mathrm{~V}\right)$. The PPy is reduced to its neutral state $\left(\mathrm{PPy}^{0}\right)$ and to compensate for the negative charge of the immobile DBS anions, Na cations from the electrolyte diffuse into the film. When the PPy is oxidised $\left(\mathrm{V}_{\text {appl }}=0 \mathrm{~V}\right.$, $\mathrm{PPy}^{+}$), the cations are repelled from the film and it shrinks. We can summarise the process by the following redox reaction

$$
\operatorname{PPy}^{+}\left(\mathrm{DBS}^{-}\right)+\mathrm{e}^{-}+\mathrm{Na}^{+}(\mathrm{aq}) \leftrightarrow \operatorname{PPy}^{0}\left(\mathrm{DBS}^{-} \mathrm{Na}^{+}\right) .
$$

The use of only one mobile redox species has several advantages, for instance smoother muscle movement and improved stability [6].

\footnotetext{
* Author to whom correspondence should be addressed. The author is a member of the graduate school Forum Scientum.
} 


\section{Applications}

We have already demonstrated some possible applications, like moving paddles and self assembling boxes [5], and we are currently working on some more concrete devices that could be used in cell biology and nano- or picoliter chemistry.

\subsection{Sealable microvial}

Our first device is a sealable microvial. This is a micrometer sized cavity in a substrate that can be closed by a lid. The lid is activated by the $\mathrm{PPy} / \mathrm{Au}$ microactuators. We have made microvials which can be opened and closed (see figure 1) and are currently investigating a sealing mechanism to achieve a tight seal. We envisage this device as a tool in cell biology. One could catch a single cell inside the vial for single cell studies or even combine the vial with sensors and/or actuators inside to make a cell clinic. Another application area might be nano- or picoliter chemistry. Using the sealable vial one could store small amounts of chemicals, and by simply closing the lid prevent evaporation, which is a big problem with such small volumes.

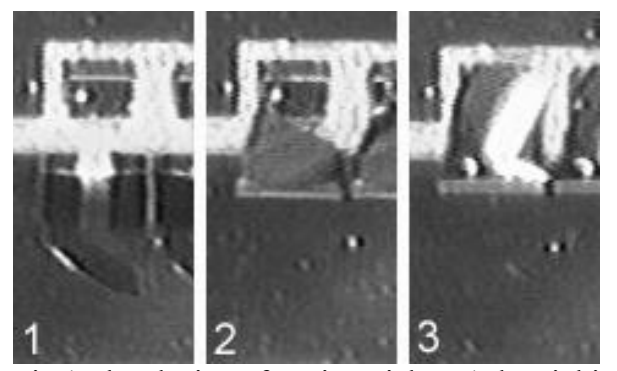

Fig.1 The closing of a microvial. In 1 the vial is open, in 2 the lid is almost perpendicular to the surface, and in 3 the vial is closed. The vial is $100 \mu \mathrm{m}$ by $130 \mu \mathrm{m}$ and $1.1 \mu \mathrm{m}$ deep. The 2 PPy/Au hinges are $100 \mu \mathrm{m}$ long and the lid is $150 \mu \mathrm{m}$ by $150 \mu \mathrm{m}$

\subsection{Cell tapper}

Recently we have succeeded in putting all the electrodes necessary for the electrochemistry (the microactuator, which is the working electrode, counter electrode and $\mathrm{Ag} / \mathrm{AgCl}$ (quasi-) reference electrode) on-chip. Figure 2 shows the device in two states of activation. This is a necessary step towards the $d r y$ system (a system in which the liquid electrolyte is replaced by a solid state electrolyte or hydrogel, which enables us to operate in normal atmosphere) but also increases the application areas of the microactuator. It enables us to use the microactuators in places were there is no space for the large counter and reference electrodes, for instance under microscopes.

We are now trying to use this as a tool for cell studies. In order to reveal cellular responses to mechanical stimuli we are planning to tap directly on leukocytes (white blood cells). The study will focus on both morphological features, such as migratory behavior, and on intracellular signaling pathways, for instance fluxes of ions over cellular membranes.

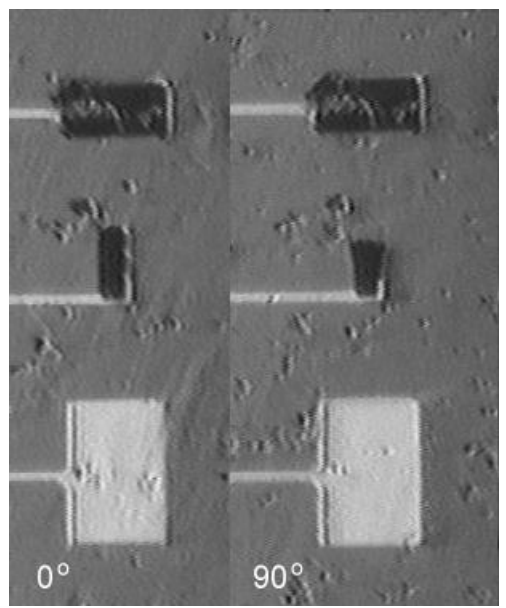

Fig. 2. The cell tapper with all electrodes on-chip. The top electrode is the (quasi-) $\mathrm{Ag} / \mathrm{AgCl}$ reference $(50 \times 100 \mu \mathrm{m})$, the middle is the microactuator $(70 \times 20 \mu \mathrm{m})$, and the bottom electrode is the Au counter electrode $(150 \times 100 \mu \mathrm{m})$. The left picture shows the tapper laying flat on the surface and the right picture shows it perpendicular to the surface.

\subsection{Microrobotics}

Another interesting area is microrobotics. We want to make a small robotic arm with individually addressable joints. This arm could be used for instance in catheters for minimal invasive surgery or to manipulate cells or particles.

One could also use the micromuscle to grab thin wires or nerve fibres, use them to position microdevices (align a light source to a waveguide), or move micrometer scale objects over a surface (microconveyer belt).

\section{Conclusions}

We demonstrated some applications of PPy/gold microactuators, like the sealable microvial and cell tapper. Other applications are under development.

\section{Acknowledgements}

E.J. wishes to thank the Swedish Foundation for Strategic Research (SSF) for it financial support. The micromuscle project is supported by TFR.

\section{References}

[1] R. H. Baughman, Synthetic metals 78 (1996) 339

[2] Q. Pei, O. Inganäs, Advanced materials 4 (1992) 277

[3] A. Della Santa, D. De Rossi, A. Mazzoldi, Smart Mater. Struct. 6 (1997) 23

[4] T. F. Otero, J. M. Sansinena, Bioelectrochemistry and Bioenergetics 38 (1995) 411

[5] E. Smela, O. Inganäs, I. Lundström, Science 268 (1995) 1735

[6] S. Shimoda, E. Smela, Electrochimica Acta (in press) 